\title{
The Effect of Postnatal Age on the Adherence of Enterohemorrhagic Escherichia coli to Rabbit Intestinal Cells ${ }^{1}$
}

\author{
SHAI ASHKENAZI, LAURI MAY, MARK LAROCCO, EDUARDO L. LOPEZ, AND \\ THOMAS G. CLEARY \\ Division of Pediatric Infectious Diseases, Department of Pediatrics [S.A., L.M., E.L.L., T.G.C.], and Department \\ of Pathology and Laboratory Medicine [M.L.]. University of Texas Medical School at Houston.
}

Houston, Texas 77030

\begin{abstract}
Enterohemorrhagic Escherichia coli (EHEC) are associated with hemorrhagic colitis and hemolytic uremic syndrome. These illnesses are typically seen in young children, but are rare before 6 mo of age. The cause of this age restriction is unclear. Because bacterial adherence to intestinal mucosa is considered a critical initial event in pathogenesis, we studied the ontogeny of the adherence of EHEC (0157:H7 and other serotypes) isolated from children with diarrhea, hemorrhagic colitis, or hemolytic uremic syndrome. Adherence was quantitatively determined by incubating radiolabeled bacteria with viable rabbit intestinal cells, which were prepared by treating loops of distal ileum and proximal colon with EDTA, DTT, and citrate. Cells obtained from animals of different ages were studied simultaneously. The adherence of the various EHEC strains varied significantly. A non-0157:H7 $E$. coli strain $43-12$ bound best ( 35 and 32 bacteria/cell to ileal and colonic cells, respectively) with $48-60 \%$ inhibition by D-mannose and $\alpha$-methyl mannoside $(p<0.01)$ and 20 $28 \%$ inhibition by $L$-fucose $(p<0.05)$, but no significant inhibition by other carbohydrates. Analysis of variance and polynomial regression showed that postnatal age significantly affected the adherence to ileal and colonic cells. Adherence during the 1st wk of life was 13-19\% of that in the adult animal; it increased gradually, reaching the adult level at about 4 wk of age. Our study shows that postnatal age affects the adherence of EHEC to intestinal cells. These findings are compatible with postnatal development of gut receptors and may be relevant to the age-related risk of EHEC disease in children. (Pediatr Res 29: 14-19, 1991)
\end{abstract}

\section{Abbreviations}

EHEC, enterohemorrhagic Escherichia coli HUS, hemolytic uremic syndrome SLT, Shiga-like toxin

Cytotoxin-producing Escherichia coli have been recently recognized as a cause of nonbloody diarrhea and hemorrhagic colitis

Received March 7, 1990; accepted September 7, 1990.

Correspondence: Thomas G. Cleary, M.D., Division of Pediatric Infectious Diseases, University of Texas Medical School, 6431 Fannin Street, Room 1.739, Houston, TX 77030 .

Supported by Grant HD-13021 from the National Institutes of Health and by a grant from the Thrasher Research Fund.

'Presented in part at the Annual Meeting of the Society for Pediatric Research. May 1990, Anaheim, CA. and they play a major pathogenic role in the development of classic HUS (1-3). Prospective studies have shown that these organisms are a major bacterial cause of infectious diarrhea in certain areas $(4,5)$ and are related to $75-94 \%$ of HUS cases $(5$, 6 ). These bacteria include $E$. coli serotypes $0157: \mathrm{H} 7$ and $026: \mathrm{H} 11$ and a variety of other $E$. coli serotypes that are often referred to as EHEC or verocytotoxin-producing $E$. coli $(2,7)$.

In addition to toxin production, adherence of bacteria to the intestinal mucosa is considered a critical initial step in pathogenesis $(8,9)$. Attachment enables microorganisms to resist expulsion by peristaltic clearing mechanisms and colonize the intestinal mucosa with effective toxin delivery. Adherence is usually mediated by binding of bacterial surface proteins to host receptors, which are usually carbohydrate residues on cell surface glycoproteins or glycolipids (8). Adherence of EHEC to the intestinal mucosa has been demonstrated in several animal studies (10-14). Binding of EHEC to isolated rabbit intestinal cells correlated with that to human cells (15), and experimental inoculation in rabbits caused diarrhea and morphologic damage to intestinal mucosa $(10,11,13)$.

Age is a major determinant in disease caused by EHEC. Both hemorrhagic colitis and HUS typically occur in children 1 to 4 $y$ of age, but are very rare in the first 6 mo of life $(2,5,6)$. The reasons for the age-related susceptibility to EHEC disease are currently unclear.

Postnatal age has a significant influence on the development of the intestinal tract, appearance of surface proteins and carbohydrates, and binding of various bacteria (16-19). As yet, there are no ontogenic studies on the intestinal adherence of EHEC. The purpose of our work was to study the effect of postnatal age on the adherence of EHEC strains to intestinal cells, using a quantitative method that has been previously described $(17,20$, 21).

\section{MATERIALS AND METHODS}

Bacteria. Clinical isolates of $E$. coli strains from children with watery diarrhea, hemorrhagic colitis, or HUS (Table 1) were studied. E. coli serotype $026: \mathrm{H} 11$ strain $\mathrm{H} 30$ is a reference strain that was originally described by Konowalchuk et al. (7). E. coli serotype $0157: \mathrm{H} 7$ strain $212-2$ and $E$. coli untypable:H21 strain 43-12 were isolated from children with diarrhea or HUS, respectively (5). Serotyping of these strains was performed by R. Wilson at the E. coli Reference Center, Pennsylvania State University. $E$. coli serotype $0157: \mathrm{H} 7$ strain 987 was obtained from $\mathrm{M}$. Osterholm, Minnesota Department of Public Health. E. coli serotype 09:H4, strain HS, a human fecal commensal that has been used as a negative control in many studies (15), was also examined. Stock bacteria were stored in $10 \%$ glycerol at $-70^{\circ} \mathrm{C}$. For the assay, bacteria were grown in $10 \mathrm{~mL}$ of Penassay broth 
(Difco Laboratories, Detroit, MI) without aeration. Radiolabeled bacteria were prepared by adding $\left[{ }^{3} \mathrm{H}\right]$ thymidine $(1 \mathrm{mCi} / \mathrm{mL}, 25$ $\mathrm{Ci} / \mathrm{mmol}$; ICN Radiochemicals, Irvine, CA), $0.1 \mathrm{mCi} / 10 \mathrm{~mL}$ Penassay broth. After overnight growth at $37^{\circ} \mathrm{C}$, bacteria were harvested by centrifugation $(8000 \times g, 10 \mathrm{~min})$ and washed twice in PBS. Mannose $(10 \mathrm{mg} / \mathrm{mL})$-sensitive agglutination of guinea pig erythrocytes by the bacteria was examined.

Cytotoxicity of cell-free extracts of the bacteria on HeLa cells was quantitatively determined as previously described (22). Neutralization studies were performed by preincubation with antiserum against Shiga toxin, which also neutralizes SLT-I, or antiserum against SLT-II (22) to determine the type of toxin produced.

DNA hybridization studies were performed to determine the presence of the structural genes for Shiga toxin, SLT-I, or SLTII in the strains studied. The DNA probes described by Newland and Neill (23) were used. The probe was extracted from low temperature-gelling agarose and labeled by nick translation with ${ }^{32}$ P-labeled 5'-deoxycytidine triphosphate (Dupont, NEM Research Products, Boston, MA). Bacterial colonies were transferred to Whatman 541 filter papers, lysed as described (24), and hybridized under stringent conditions $\left[50 \%\right.$ formamide, $42^{\circ} \mathrm{C}, 2$ $\times$ SSC (SSC, $0.5 \mathrm{M} \mathrm{NaCl}$ plus $0.015 \mathrm{M}$ sodium citrate), $18 \mathrm{~h}$ ] (22). On each filter, the following positive and negative control strains were placed: Shigella dysenteriae serotype 1 strain $60 \mathrm{R}$ (a Shiga toxin producer), E. coli 026:H11 strain H30 (a SLT-I producer), E. coli C600 (933w) (a SLT-II producer), and E. coli C600 (a non-cytotoxin-producing strain).

Preparation of isolated intestinal cells. The study was approved by the Animal Welfare Committee of the University of Texas Medical School at Houston. New Zealand White rabbits (Ray Nichols, Lumberton, TX) of various ages were used. The day of birth was considered as $\mathrm{d} 0$. Rabbits were killed by i.v. injection of sodium pentothal and loops of the terminal ileum or proximal colon were obtained. After washings with saline, intestinal cells were released from these loops by treatment with solutions containing EDTA, citrate, and DTT as described in detail (17). Cells were suspended in $20 \mathrm{mM}$ morpholinoethane sulfonate buffer containing $140 \mathrm{mM} \mathrm{NaCl}$ and $1 \mathrm{mM} \mathrm{CaCl}_{2}$. The viability of the intestinal cells was monitored by trypan blue exclusion.

Assay for bacterial adherence to intestinal cells. A suspension of intestinal cells $\left(200 \mu \mathrm{L}, 10^{7}\right.$ cells $\left./ \mathrm{mL}\right)$ was incubated with radiolabeled bacteria $\left(100 \mu \mathrm{L}, 6 \times 10^{9}\right.$ bacteria $\left./ \mathrm{mL}\right)$ at $37^{\circ} \mathrm{C}$ in a rotating rack $(8 \mathrm{rpm})$ for $45 \mathrm{~min}$. The reaction was terminated by adding $2.5 \mathrm{~mL}$ saline and centrifuging $(500 \times \mathrm{g}, 5 \mathrm{~min})$ to sediment the intestinal cells; the supernatant, which contained nonadherent bacteria, was discarded. The intestinal cells were separated from remaining unattached bacteria by a discontinuous density gradient centrifugation with Percoll (Sigma Chemical Co., St. Louis, MO), as described $(17,20)$. The reliability of the separation procedure was repeatedly tested. The layer of the intestinal cells with the adhered bacteria was transferred to $3 \mathrm{~mL}$ of scintillation fluid and counted for radioactivity.

To determine whether $\left[{ }^{3} \mathrm{H}\right]$ thymidine could be released from the bacteria and incorporated by the intestinal cells, the following experiments were undertaken. First, bacteria were incubated under the same experimental conditions, but without intestinal cells. The amount of radioactivity detected in the supernatant, after sedimenting the bacteria, was 1 to $5 \%$ of the original radioactivity. When this amount of radioactivity (or even 10fold higher) was added to the suspension of intestinal cells and incubated under our experimental conditions, no radioactivity was incorporated into the intestinal cells. To determine if cytotoxins are released under our experimental conditions, after completing the assay, the supernatant was filter-sterilized and examined for cytotoxicity on HeLa cells as described (22).

Certain carbohydrates, including D-mannose, $\alpha$-methyl mannoside, D-glucose, L-fucose, D-galactose, and lactose (Sigma Chemical Co.), were studied for their ability to inhibit the adherence of EHEC strains. In these experiments, radiolabeled bacteria $\left(100 \mu \mathrm{L}, 6 \times 10^{9}\right.$ bacteria/mL) were preincubated with the carbohydrates ( $33 \mu \mathrm{L}$, final concentration $10 \mathrm{mg} / \mathrm{mL}$ in PBS) at $37^{\circ} \mathrm{C}$ for $10 \mathrm{~min}$. Simultaneous preincubation with PBS (the diluent) was used for controls. Intestinal cells were then added and the assay completed as described above.

Electron microscopy. Morphologic observations with electron microscopy were performed with $E$. coli $43-12$ and 212 , the strains with highest and lowest adherence, respectively. Bacteria negatively stained with $2 \%$ phosphotungstanic acid were examined by electron microscopy (JEOL $100 \mathrm{CX} 2$, Japan) for the presence of surface appendages. Scanning electron microscopy was performed essentially as described (17). Intestinal sections were placed on dot blot apparatus and the exposed surfaces were incubated with bacteria $\left(0.2 \mathrm{~mL}, 6 \times 10^{9}\right.$ bacteria $\left./ \mathrm{mL}, 45 \mathrm{~min}\right)$. After washing three times with PBS, the exposed areas were cut, fixed with $2 \%$ glutaraldehyde, $(1 \mathrm{~h})$, and postfixed with $2 \%$ osmium tetraoxide $(1 \mathrm{~h})$. Samples were then dehydrated with ethanol, air dried $(5 \mathrm{~min})$, treated with hexamethyldisilazane, sputter-coated with gold, and examined with a JSM-820 scanning electron microscope (JEOL).

Statistical analysis. All experiments were performed in duplicate or triplicate and repeated three to five times. Analysis of variance was used to determine the significance of the differences among the various study groups, followed by $t$ test for multiple comparisons. The correlation between postnatal age and adherence was determined by a polynomial regression analysis.

\section{RESULTS}

EHEC strains used in this study produced high levels of cytotoxic activity when grown for $48 \mathrm{~h}$ and sonicated. Neutralization studies and DNA hybridization showed that the strains produced one or both SLT (Table 1). However, under our experimental conditions, no cytotoxic activity was detected in the supernatant after completing the adherence assays with these bacteria. Of the strains studied, only $E$. coli strain 43-12 caused mannose-inhibitable hemagglutination of guinea pig erythrocytes (8).

Adherence of various EHEC strains to rabbit intestinal cells. Adherence to intestinal cells released from the terminal ileum of adult rabbits showed marked differences among the various EHEC strains (Fig. 1). E. coli 43-12 was most adherent (about 35 bacteria/ileal cell) and $E$. coli $\mathrm{H} 30$ and 987 showed moderate adherence (7-8 bacteria/cell), whereas $E$. coli $212-2$ showed considerably lower binding ( $1-2$ bacteria/cell), which was similar to that of a control, commensal $E$. coli strain HS. The differences in the adherent capability of the various EHEC strains were significant. Strain 43-12 was significantly more adherent than

Table 1. Characterization of E. coli strains used in this study

\begin{tabular}{lllll}
\hline E. coli serotype & Strain & \multicolumn{1}{c}{ Source } & $\begin{array}{c}\text { Cytotoxin } \\
\text { production* }\end{array}$ & $\begin{array}{c}\text { Agglutination } \\
\text { of guinea pig } \\
\text { erythrocytes }\end{array}$ \\
\hline $026: \mathrm{H} 11$ & $\mathrm{H} 30$ & Nonbloody diarrhea & SLT-I & - \\
$0157: \mathrm{H} 7$ & $212-2$ & Hemorrhagic colitis & SLT-II & \\
$0157: \mathrm{H} 7$ & 987 & Hemorrhagic colitis & SLT-I/II & + \\
Untypable:H21 & $43-12$ & Hemolytic uremic syndrome & SLT-II & + \\
\hline
\end{tabular}

\footnotetext{
* The type of cytotoxin produced was determined by neutralization studies and hybridization with specific DNA probes.
} 


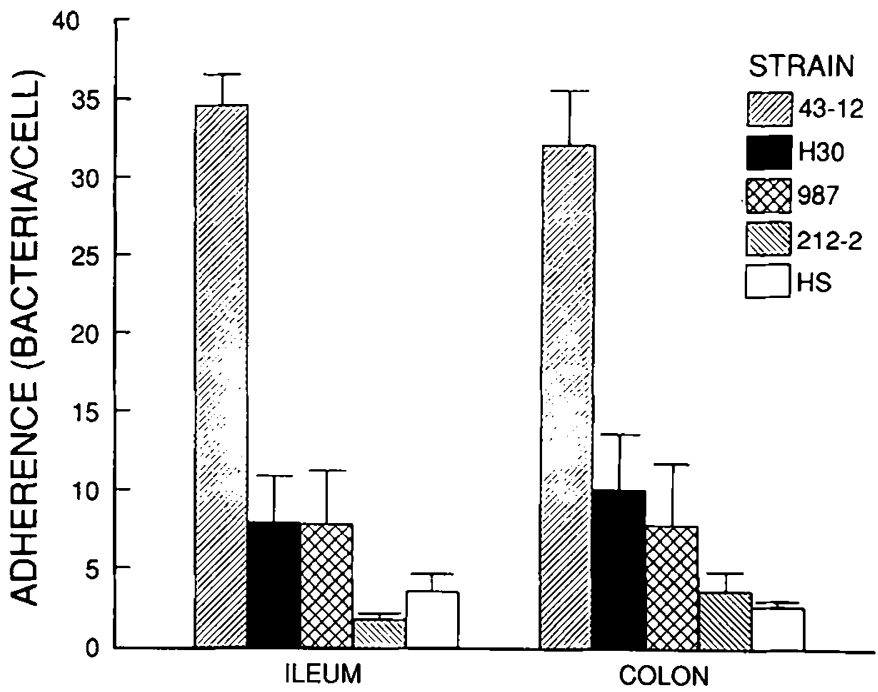

Fig. 1. The adherence of EHEC strains and the commensal HS to ileal and colonic cells obtained from adult ( $>35 \mathrm{~d}$ ) rabbits. Adherence was quantitatively determined with radiolabeled bacteria under standard conditions (incubation at $37^{\circ} \mathrm{C}, 45 \mathrm{~min}$ ). Results presented as mean \pm SEM of five determinations. The strains differed significantly in adherence (see text).

Table 2. Adherence of EHEC strains to ileal cells of rabbits of different age groups

\begin{tabular}{ccccc}
\hline \multirow{2}{*}{$\begin{array}{c}\text { Age group } \\
\text { (wk of life) }\end{array}$} & \multicolumn{4}{c}{ Adherence (bacteria/cell) of EHEC strain $\dagger$} \\
\cline { 2 - 5 } & \multicolumn{1}{c}{$43-12$} & H30 & 987 & $212-2$ \\
\hline 1 & $4.5 \pm 1.8$ & $2.6 \pm 1.1$ & $1.9 \pm 1.4$ & $1.1 \pm 1.0$ \\
2 & $8.8 \pm 2.2$ & $2.8 \pm 1.6$ & $2.8 \pm 2.1$ & $1.0 \pm 0.9$ \\
3 & $19.1 \pm 3.1$ & $3.4 \pm 1.4$ & $2.9 \pm 2.0$ & $1.3 \pm 0.8$ \\
4 & $32.8 \pm 4.5$ & $7.8 \pm 2.4$ & $7.9 \pm 3.9$ & $1.5 \pm 1.0$ \\
5 & $36.1 \pm 6.0$ & $8.4 \pm 2.2$ & $8.0 \pm 3.6$ & $1.8 \pm 0.5$ \\
$>5$ & $34.7 \pm 2.1$ & $8.0 \pm 3.1$ & $7.9 \pm 3.4$ & $1.8 \pm 0.6$ \\
\hline
\end{tabular}

* The day of birth was considered $d 0$.

$\dagger$ Results presented as mean \pm SEM of five determinations for $E$. coli 43-12 and 212-2 and three determinations for $E$. coli $\mathrm{H} 30$ and 987 . For each EHEC strain, there was a significant $(p<0.02$ to $p<0.005)$ increase in adherence with increasing age.

H30 ( $p<0.005)$ and $987(p<0.002)$; strains 43-12, H30, and 987 were significantly more adherent to ileal cells than strain $212-2$ ( $p<0.0001, p<0.05$, and $p<0.0001$, respectively). Strains H30 and 987 were not significantly different from each other.

Similar trends were noticed in the adherence to intestinal cells released from the proximal colon of adult animals (Fig. 1). $E$. coli 43-12 was most adherent (about 32 bacteria/cell), followed by $E$. coli $\mathrm{H} 30$ and 987 ( $8-10$ bacteria/cell); again, $E$. coli $212-2$ adhered at a level similar to the control strain (2-4 bacteria/cell). The differences among the strains were significant. Strain 43-12 was significantly more adherent than $\mathrm{H} 30(p<0.05)$ and 987 $(p<0.001)$; strains $43-12$ and 987 were significantly more adherent to colonic cells than strain 212-2 ( $p<0.0001$ and $p<$ 0.01 , respectively), whereas strain $\mathrm{H} 30$ was not significantly different $(p=0.10)$. Strains $\mathrm{H} 30$ and 987 were not significantly different from each other.

The collected intestinal cells were also stained with Giemsa and examined with light microscopy. This validated the attachment of bacteria to the cells, but to determine precisely to what surface of the cells the bacteria were attached, electron microscopy was necessary.

Effect of postnatal age on adherence of EHEC to ileal cells. The age-related adherence of the various EHEC strains to ileal cells is shown in Table 2 . Animals were grouped by weeks of age.
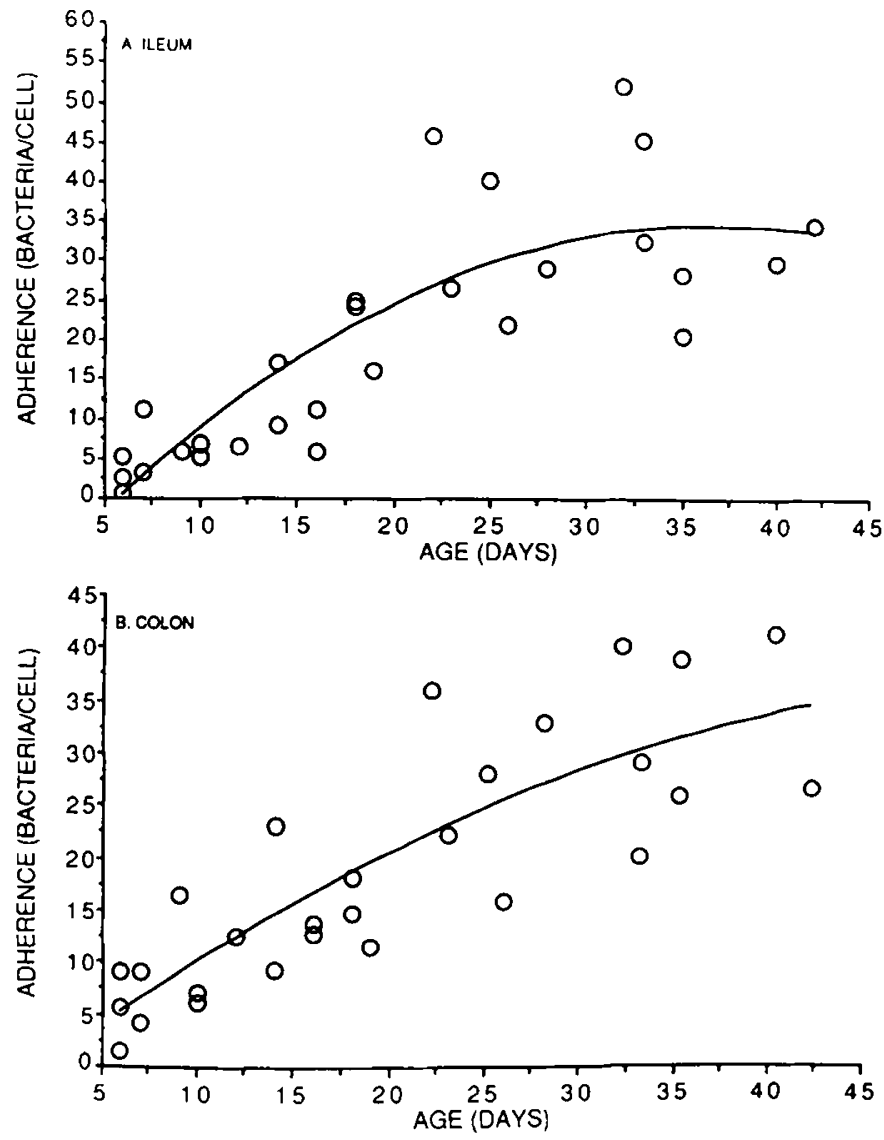

Fig. 2. The adherence of $E$. coli $43-12$ to rabbit ileal $(A)$ and colonic $(B)$ cells as a function of postnatal age. The day of birth was considered $\mathrm{d} 0$. The results obtained with all individual animals up the age of $45 \mathrm{~d}$ are shown (three older rabbits, 2-12 mo old, are not shown). Polynomial regression analysis showed a significant correlation between adherence and postnatal age ( $p=0.0001$ for both ileal and colonic cells).

Table 3. Adherence of EHEC strains to colonic cells of rabbits of different age groups

\begin{tabular}{ccrcc}
\hline \multirow{2}{*}{$\begin{array}{c}\text { Age group } \\
\text { (wk of life) }\end{array}$} & \multicolumn{4}{c}{ Adherence (bacteria/cell) of EHEC strain $\dagger$} \\
\cline { 2 - 5 } & \multicolumn{1}{c}{$43-12$} & \multicolumn{1}{c}{ H30 } & 987 & \multicolumn{1}{c}{$212-2$} \\
\hline 1 & $6.0 \pm 1.5$ & $4.4 \pm 2.1$ & $4.2 \pm 2.9$ & $2.3 \pm 1.1$ \\
2 & $12.4 \pm 3.2$ & $4.2 \pm 1.1$ & $6.3 \pm 3.4$ & $2.6 \pm 1.1$ \\
3 & $14.2 \pm 1.1$ & $5.0 \pm 1.0$ & $6.5 \pm 2.9$ & $2.1 \pm 1.1$ \\
4 & $27.2 \pm 3.7$ & $9.3 \pm 2.7$ & $7.7 \pm 1.6$ & $3.2 \pm 1.2$ \\
5 & $31.3 \pm 3.9$ & $11.2 \pm 6.0$ & $7.3 \pm 2.7$ & $3.3 \pm 1.0$ \\
$>5$ & $32.3 \pm 3.7$ & $10.2 \pm 3.6$ & $7.9 \pm 3.9$ & $3.7 \pm 1.2$ \\
\hline
\end{tabular}

* The day of birth was considered $d 0$.

+ Results presented as mean \pm SEM of five determinations for $E$. coli 43-12 and 212-2 and three determinations for E. coli $\mathrm{H} 30$ and 987 . For each EHEC strain, there was a significant $(p<0.05$ to $p<0.002)$ increase in adherence with increasing age.

Increased binding with age was found. $E$. coli $43-12$, the most adherent strain, demonstrated the clearest influence with age ( $p$ $<0.005$ ). Binding during the 1 st week of life was only $13 \%$ of that in the adult animal; it increased gradually, reaching the adult level at about $4 \mathrm{wk}$ of age. The differences in the adherent capabilities of animals of various age groups were significant by regression analysis; significant differences from the adult level of binding were found up to the age of $3 \mathrm{wk}$. The adherence of $E$. coli $\mathrm{H} 30,987$, and $212-2$ also increased significantly with age ( $p$ $<0.02, p<0.02$, and $p<0.05$, respectively).

The adherence of $E$. coli $43-12$ to ileal cells of the individual rabbits is shown in Figure $2 A$. Because the relation between 

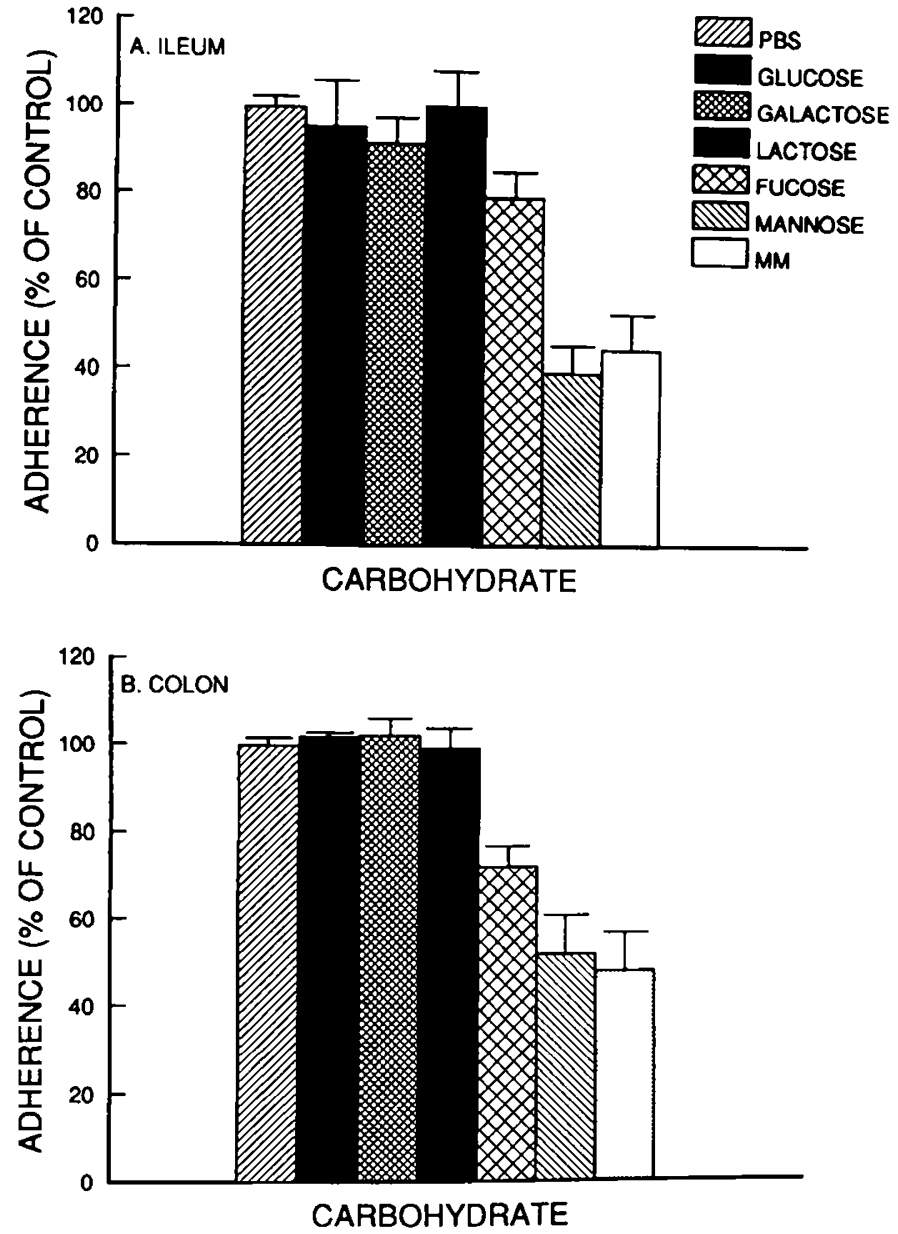

Fig. 3. Effect of carbohydrates on the adherence of $E$. coli $43-12$ to rabbit ileal $(A)$ and colonic $(B)$ cells. Radiolabeled bacteria were preincubated with carbohydrates (final concentration $10 \mathrm{mg} / \mathrm{mL}$ in PBS, $37^{\circ} \mathrm{C}, 10 \mathrm{~min}$ ) or PBS (control). Intestinal cells were then added and the adherence assay performed under the standard conditions (incubation at $37^{\circ} \mathrm{C}, 45 \mathrm{~min}$ ). Results are expressed as percent adherence of control cells incubated with PBS, and represent mean \pm SEM of five determinations for D-mannose and L-fucose, and of three determinations for the other carbohydrates. Analysis of variance showed significant inhibition by D-mannose, $\alpha$-methyl mannoside ( $M M)$, and L-fucose.
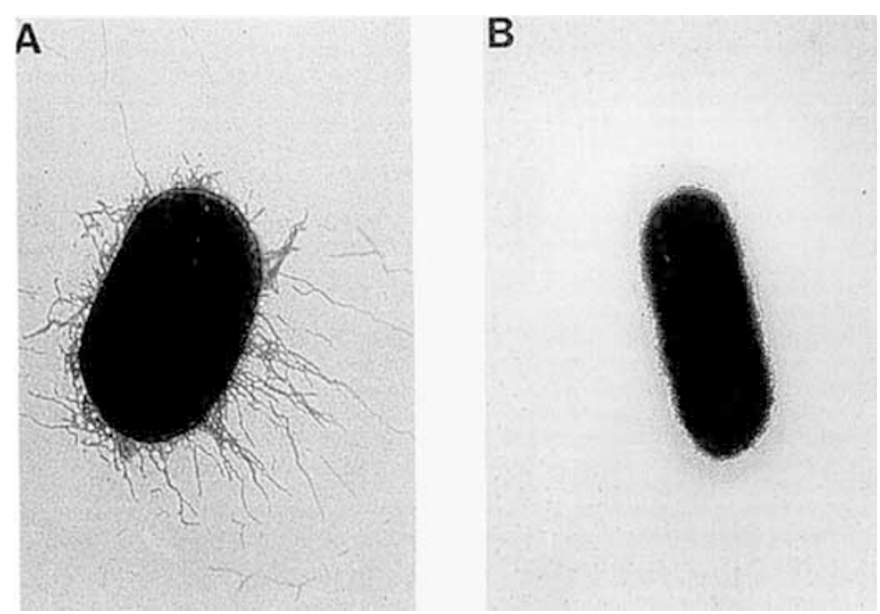

Fig. 4. Electron micrographs of negatively stained EHEC strains. Surface fimbriae were seen only on $E$. coli strain 43-12 $(A)$, which showed the highest binding, but not on $E$. coli $212-2(B)$.
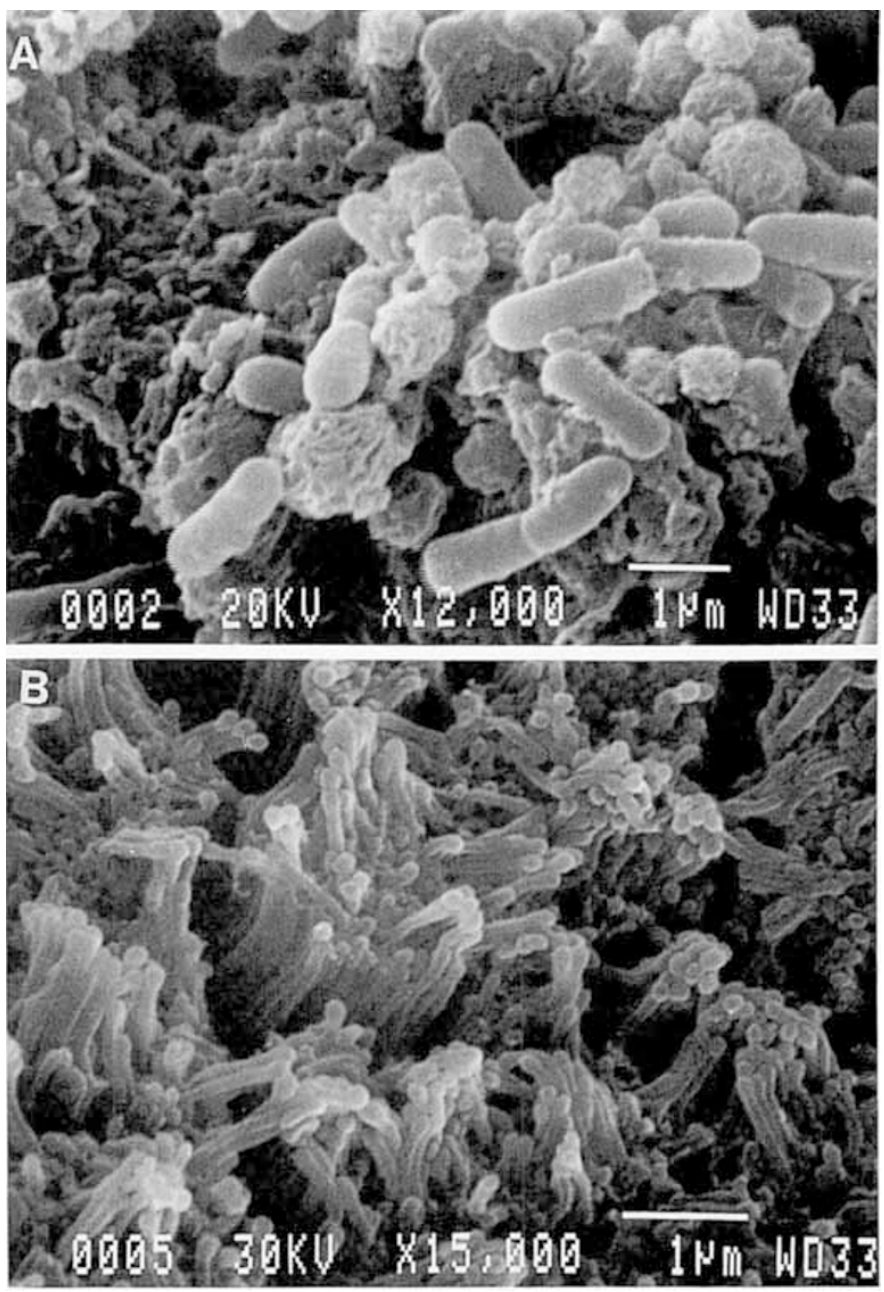

Fig. 5. Scanning electron micrographs of adherence of EHEC strains to ileal brush border of rabbits. $A$, adherence of $E$. coli strain 43-12 to the brush border is seen with mild tissue damage. $B$, after incubation with $E$. coli $212-2$, the intestinal brush border remained generally intact, with very few bacteria attached.

binding and postnatal age was not linear, polynomial regression analysis was used. Animal age significantly influenced the binding, although notable variability in the adherent capability of individual animals occurred.

Effect of postnatal age on adherence of EHEC to colonic cells. The adherence of EHEC strains to colonic cells obtained from various age groups of animals is shown in Table 3. Ahderence to colonic cells also increased with age for $E$. coli $43-12$, H30, 987, and 212-2 $(p<0.002, p<0.02, p<0.02$, and $p<0.05$, respectively); it reached the adult level of adherence at 4-5 wk of age.

The adherence of $E$. coli 43-12 to colonic cells of the individual rabbits is shown in Figure $2 B$. Polynomial regression analysis showed a significant correlation between age and binding.

Inhibition of binding by carbohydrates. The effect of preincubation with carbohydrates on the binding of $E$. coli 43-12 to ileal and colonic cells is shown in Figure 3. The adherence of this strain, which was the most adherent of the EHEC strains tested, showed considerable inhibition by certain carbohydrates. The adherence to ileal cells (Fig. $3 \mathrm{~A}$ ) in the presence of D-mannose or $\alpha$-methyl mannoside was 40 and $45 \%$ of the control, respectively; fucose reduced the binding to $80 \%$ of control, whereas the other carbohydrates did not show inhibitory activity. Analysis of variance showed significant differences among the groups $(p$ $=0.014)$, with significant inhibition by D-mannose $(p<0.001)$, $\alpha$-methyl mannoside, and L-fucose ( $p<0.01$ for each). Binding to colonic cells (Fig. $3 B$ ) showed significant inhibition by D- 
mannose and $\alpha$-methyl mannoside (52 and $48 \%$ binding of control, respectively, $p<0.01$ ), and by L-fucose ( $72 \%$ binding of control, $p<0.05$ ). Mannose-related binding could not explain the entire adherent capability of $E$. coli strain 43-12. In the presence of mannose $(10 \mathrm{mg} / \mathrm{mL})$, although significant reduction of the binding was noted, the residual mannose-independent binding of E. coli 43-12 was 2- to 7-fold higher than that of the other $E$. coli strains.

D-Mannose and $\alpha$-methyl mannoside caused 10 to $20 \%$ inhibition in the binding of $E$. coli strain $\mathrm{H} 30$ to intestinal cells, but this failed to reach statistical significance. L-Fucose did not inhibit the binding of $E$. coli strain $\mathrm{H} 30$, nor did D-mannose, $\alpha$ methyl mannoside, or L-fucose inhibit the binding of the other E. coli strains $(987,212-2$, or HS).

Electron microscopy. Electron micrographs of negatively stained bacteria showed that $E$. coli strain $43-12$, the most adherent strain, had surface fimbriae, whereas $E$. coli strain $212-$ 2 did not show any surface appendage (Fig. 4). Scanning electron microscopy demonstrated the avid adherence of $E$. coli strain 43-12 (Fig. 5). This organism bound in high numbers to the brush border of intestinal mucosa with mild tissue damage. In contrast, after incubation with $E$. coli $212-2$, under the same experimental conditions, the intestinal brush border was generally intact, with very few bacteria attached (Fig. 5B). These observations correlated with the radiolabeled adherence assays.

\section{DISCUSSION}

The main finding of our study was that the adherence of EHEC to rabbit intestinal cells was very low in the neonatal animal and increased significantly with postnatal age. The agedependent adherence noted for each EHEC strain was most prominent for $E$. coli strain 43-12, the most adherent strain, whose binding was inhibited by D-mannose and L-fucose. These data suggest that the availability of mannose/fucose-sensitive receptors and other receptors for EHEC is gradually developed or unmasked during postnatal maturation of intestinal enterocytes.

Animal studies have demonstrated that postnatal development of intestinal cells influences the appearance of mucosal proteins, carbohydrates, and digestive enzymes $(25,26)$. In humans, the level of mucosal digestive enzymes is influenced by postnatal age $(25,27)$. Developmental changes in surface carbohydrate residues may obviously affect bacterial adherence. Animals studied with a few other bacteria have shown age-related differences in bacterial attachment to isolated intestinal cells or brush border membranes (16-19). In particular, the adherence of $E$. coli strain RDEC-1, a rabbit pathogen, to rabbit brush border membranes increases with age (18), as does the attachment of Salmonella typhimurium to rat intestinal cells (19).

Our study also showed that mannose and fucose demonstrated considerable, but incomplete, inhibition of the binding of $E$. coli strain 43-12 to ileal and colonic cells. It seems that mannoseinhibitable adherence does not represent a single entity and that several receptor sites, all of which are blocked partially or completely by mannose, may be involved. For instance, we have previously shown that although both $E$. coli $0128: \mathrm{H} 4$ and $S$. typhimurium showed mannose-sensitive binding to guinea pig enterocytes, aromatic $\alpha$-glycosides of mannose were 500 - to 1000 -fold more effective than mannose in inhibiting the binding of $E$. coli, but less effective than mannose with $S$. typhimurium (20). This suggested that mannose-binding pili of $E$. coli, but not of $S$. typhimurium, possessed a hydrophobic region next to the mannose-binding site, and exemplified the complexity of the mannose-binding mechanism. Considerable differences were found in the protein subunits of mannose-sensitive adhesins of various bacteria, which may occur on the surface of the bacteria as pili or as part of the outer membranes (28). This proposed diversity of the mannose-binding mechanisms may explain why postnatal age increased the adherence of $S$. typhimurium (19) but not that of $E$. coli $0128: \mathrm{H} 4$ (17), although both bacterial strains attached by a mannose-sensitive mechanism. Also, the different growth conditions and experimental systems that have been used may be of importance. With regard to mannosespecific binding of EHEC, a previous study showed that one of five $E$. coli $0157: \mathrm{H} 7$ strains demonstrated mannose-sensitive binding to intestinal cells (15). This phenomenon has not been shown before in a non-0157:H7 EHEC strain. Determination of the carbohydrate-inhibition of the adherence of EHEC is certainly only a preliminary step in characterization and isolation of the receptor site(s) or the bacterial surface structures that are involved.

In addition, our study showed significant differences in the adherent capability of various clinical isolates of EHEC. Similar variability has been shown before in $E$. coli $0157: \mathrm{H} 7(15,29)$, the prototype EHEC serotype, but not in non-0157:H7 strains. The adherence of the EHEC strain with minimal binding was not distinct from that of a nonpathogen, commensal $E$. coli strain. It remains to be determined if the adherence properties of EHEC strains influence their clinical presentation with regard to the attack rate, development of bloody or nonbloody diarrhea, or rate of developing systemic complications, such as HUS. $E$. coli $43-12$, the most adherent strain in our study, was isolated from a child with HUS.

No cytotoxic activity was demonstrated in the adherence assays. It is unlikely that toxin has any effect on adherence in these short-term assays, inasmuch as cytotoxicity assays typically require 24 to $72 \mathrm{~h}$ to detect cell detachment and intestinal cells are unaffected by incubation with toxin for 5 to $10 \mathrm{~h} \mathrm{(30)}$.

Caution is obviously necessary in extrapolating in vitro findings with animal models to human disease. Previous studies, however, have shown that the adherence of EHEC to rabbit enterocytes and brush borders did correlate with the binding to human enterocytes and that the binding was primarily to the apical membranes of rabbit enterocytes, rather than to basolateral surfaces (15). Inoculation of rabbits with EHEC strains has shown that these bacteria adhered in vivo to intestinal mucosal surfaces, causing damage to ileal brush borders $(10,11,13)$, and the inoculated animals developed diarrhea. Thus, rabbits seem to be an appropriate animal model to study the adherence of EHEC. Postnatal maturation of bacterial receptor sites in humans has also been demonstrated. During the first few days of life, the adherence of streptococci to oral mucosal cells (31) and staphylococci to nasal mucosa (32) was lower than that in adults.

Postnatal developmental maturation of the adherence process of EHEC to the intestinal tract is consistent with epidemiologic data on infections with these organisms. Intestinal and systemic diseases related to these organisms are typically seen in young children, but are very rare before 6 mo of age. This is true in both breast-fed and non-breast-fed infants, and may be explained by the reduced binding of EHEC during the early postnatal period. It should be emphasized, however, that the development of human disease is obviously a complex process that may depend also on other host factors. Availability of cytotoxinbinding receptors in the intestine or in other tissues may play a role (33), as may serum and secretory antibodies against virulence traits of these bacteria. It has been presumed that the development of specific secretory or serum antibodies accounted for the reduced incidence of infections with EHEC after childhood, and that the increased incidence of these infections in the elderly might be related to waning immunity in that age group (2), although the precise role of these and other potential contributors has not yet been clarified.

Acknowledgments. The authors thank Richard Wilson for serotyping the $E$. coli strains, Rory Van for technical assistance, and Anne Wright for word processing. 


\section{REFERENCES}

1. Riley LW, Remis RS, Helgerson SD, McGee HB, Wells JG, Davis BR, Heber RJ, Olcott ES, Johnson LM, Hargrett NTG, Blake PA, Cohen ML 1983 Hemorrhagic colitis associated with a rare Escherichia coli serotype. N Engl J Med 308:681-685

2. Karmali MA 1989 Infection by verocytotoxin-producing Escherichia coli. Clin Microbiol Rev 2:15-38

3. Cleary TG 1988 Cytotoxin-producing Escherichia coli and the hemolytic uremic syndrome. Pediatr Clin North Am 35:485-501

4. Pai $\mathrm{CH}$, Ahmed N, Lior H, Johnson WM. Sims HV, Woods DE 1988 Epidemiology of sporadic diarthea due to verocytotoxin-producing Escherichia coli: a two-year prospective study. J Infect Dis 157:1054-1057

5. Lopez EL, Diaz M, Grinstein S, Devoto S, Mendilaharzu F, Murray BE Ashkenazi S, Rubeglio E, Woloj M, Vasquez M, Turco M, Pickering LK, Cleary TG 1989 Hemolytic uremic syndrome and diarrhea in Argentine children: the role of Shiga-like toxins. J Infect Dis 160:469-475

6. Karmali MA, Petric M, Lim C, Fleming PC, Arbus GS, Lior H 1985 The association between hemolytic uremic syndrome and infection by Verotoxinproducing Escherichia coli. J Infect Dis 151:775-782

7. Konowalchuk J, Speirs JI, Stavric S 1977 Vero response to a cytotoxin of Escherichia coli. Infect Immun 18:775-779

8. Ofek I, Beachey EH 1980 Bacterial adherence. Adv Intern Med 25:503-532

9. Beachey EH 1981 Bacterial adherence:adhesin-receptor interactions mediating the attachment of bacteria to mucosal surfaces. J Infect Dis 143:325-345

10. Potter ME, Kaufmann AF. Thomason BM, Blake PA, Farmer III JJ 1985 Diarrhea due to Escherichia coli $0157: \mathrm{H} 7$ in the infant rabbit. J Infect Dis 152:1341-1343

11. Pai CH, Kelly JK, Meyers GL 1986 Experimental infection of infant rabbits with verotoxin-producing Escherichia coli. Infect Immun 51:16-23

12. Tzipori S, Wachsmuth IK, Chapman C, Birner R, Brittingham J, Jackson C, Hogg J 1986 The pathogenesis of hemorrhagic colitis caused by Escherichia coli 0157:H7 in gnotobiotic piglets. J Infect Dis 154:712-716

13. Sherman P, Soni R, Karmali M 1988 Attaching and effacing adherence of vero cytotoxin producing Escherichia coli to rabbit intestinal epithelium in vivo. Infect Immun 57:756-761

14. Karch H, Heesemann J, Laufs R, O'Brien AD, Tacket CO, Levine MM 1987 A plasmid of entero-hemorrhagic Escherichia coli $0157: \mathrm{H} 7$ is required for expression of a new fimbrial antigen and for adhesion to epithelial cells. Infect Immun 55:455-461

15. Durno C, Soni R, Sherman P 1989 Adherence of verocytotoxin-producing Escherichia coli serotype 0157:H7 to isolated epithelial cells and brush border membranes in vivo: role of type 1 fimbriae (pili) as a bacterial adhesin expressed by strain CL-49. Clin Invest Med 12:194-200

16. Mahmmod A, Torres-Pinedo R 1983 Postnatal changes in lectin binding to microvillus membrane from rat intestine. Biochem Biophys Res Commun 2:400-406

17. Ashkenazi S, Mirelman D 1984 The effect of postnatal age on the adherence of Shigella flexneri. Escherichia coli 0124 , and E. coli 0128 to guinea pig intestinal cells. Pediatr Res 18: I 366-1371

18. Cheny CP. Boedeker EC 1984 Rabbit mucosal receptors for enteropathogenic Escherichia coli strain: appearance of bacterial receptor activity at weaning. Gastroenterology 87:821-826

19. El Monem AMA. Saad M, Oindquist BL. Lec P. Abud R. Merrick JM, Lebenthal E 1988 The effect of postnatal development on the adherence of nonfimbriated and fimbriated Salmonella typhimurium to isolated small intestinal enterocytes. Pediatr Res 24:508-511

20. Finon N, Ashkenazi S, Mirelman D, Ofek I. Sharon N 1987 Aromatic alphaglycosides of mannose are powerful inhibitors of the adherence of type 1 fimbriated Escherichia coli to yeast and intestinal epithelial cells. Infect Immun 55:472-476

21. Ashkenazi S, Mirelman D 1987 Nonimmunoglobulin fraction of human milk inhibits the adherence of certain enterotoxigenic Escherichia coli strains to guinea pig intestinal tract. Pediatr Res 22:130-134

22. Ashkenazi S, Cleary TG. Murray BE. Wanger A. Pickering LK 1988 Quantitative analysis and partial characterization of cytotoxin production by Salmonella strains. Infect Immun 56:3089-3094

23. Newland JW, Neill RJ 1988 DNA probes for Shiga-like toxins I and II and for toxin-converting bacteriophages. J Clin Microbiol 26:1292-1297

24. Maas R 1983 An improved colony hybridization method with significantly increased sensitivity for detection of single genes. Plasmid 10:296-298

25. Auricchio S, Stellato A, DeVisia B 1981 Development of brush border peptidases in human and rat intestine during fetal and neonatal life. Pediatr Res 15:991-995

26. Buts JP, DeMeyer R 1981 Postnatal proximodistal development of the small bowel mucosal mass in growing rats. Biol Neonate 40:62-69

27. Lebenthal E, Lee PC, Heitlinger LA 1983 Impact of devclopment of the gastrointestinal tract on infant feeding. J Pediatr 102:1-9

28. Eshdat Y, Speth V, Jann K 1981 Participation of pili and cell wall adhesin in the yeast agglutination activity of Escherichia coli. Infect Immun 34:980983

29. Wells JG. Davis BR, Wachsmuth IK, Riley LW, Remis RS. Sokolow R, Morris GK 1983 Laboratory investigation of hemorrhagic colitis outbreaks associated with rare Escherichia coli serotype. J Clin Microbiol 18:512-520

30. Moyer MP, Dixon PS. Rothman SW, Brown JE 1987 Cytotoxicity of shigatoxin for primary cuitures of human colonic and ileal epithelial cells. Infect Immun 55:1533-1535

31. Ofek I, Beachey EH. Eyal F, Morrison JC 1977 Postnatal development of binding of Streptococci and lipoteichoic acid by oral mucosal cells of humans. $J$ Infect Dis 135:267-274

32. Aly R, Colman J, Shinefield H, Maibach E, Strauss W 1978 Comparison of Staphylococcus adherence to nasal mucosa of infants and adults. Clin Res 26:389A(abstr)

33. Mobassaleh $M$, Donohue-Rolfe A, Jacewicz M. Keusch G Grand R 1988 Pathogenesis of Shigella diarrhea. XIII. Evidence for a developmentally regulated glycolipid receptor for Shigella toxin involved in the fluid secretory response of rabbit small intestine. J Infect Dis 157:1023-1031 